\title{
O DESEJO DE (DES)HABITAR O OUTRO: O CORPO QUARE NA (PO)ÉTICA DE WALDO MOTTA
}

\author{
THE DESIRE TO (DIS)INHABIT THE OTHER: \\ THE QUARE BODY IN WALDO MOTTA'S (PO)ETHIC(S)
}

\author{
Fernando Luis de Morais ${ }^{1}$ \\ Claudia Maria Ceneviva Nigro ${ }^{2}$
}

\begin{abstract}
RESUMO
Esquadrinhar a maneira como a linguagem (po)ética de Waldo Motta realiza experiências dinâmicas a fim de alçar corpos negros, gays e pobres - portanto, quare - à plena condição de sujeito em uma sociedade pautada pelos ditames da brancura, da heterossexualidade e do classismo - eis o objetivo deste artigo. Os poemas "Preceituário para racistas com receita de rebuçado e contra-receita de angu", "Deus furioso" e "No cu" tecem pontos de aproximação quanto à forma de representar esses corpos relegados ao limbo, operando uma transformação, uma ruptura de padrões arbitrariamente consolidados. A perspectiva da qual lançamos mão nesta análise busca focalizar esse exercício (est)eticamente poderoso, forçando um olhar renovado da materialidade corporal quare.
\end{abstract}

Palavras-chave: Materialidade corporal. Po(ética). Quare. Waldo Motta.

\begin{abstract}
This article aims to explore how Waldo Motta's poeticlethical language performs dynamic experiments in order to raise black, gay and poor bodies - therefore, quare ones - to full subject condition in a society ruled by the dictates of whiteness, heterosexuality and classism. The poems "Preceituário para racistas com receita de rebuçado e contra-receita de angu", "Deus furioso" and "No cu" create points of contact as to how to represent these bodies relegated to limbo, operating a transformation, a rupture of patterns arbitrarily instituted. The perspective from which we approach this analysis seeks to focus on this aesthetically/ethically powerful exercise, forcing a renewed look at the materiality of quare bodies.
\end{abstract}

Keywords: Materiality of bodies. (Po)ethics. Quare. Waldo Motta.

\footnotetext{
${ }^{1}$ Atualmente é doutorando no Programa de Pós-Graduação em Letras pela Universidade Estadual PaulistaUNESP/ S. J. Rio Preto. Mestre em Teoria da Literatura pelo referido programa. e-mail: dmorays_2@hotmail.com

${ }^{2}$ Atualmente é Livre Docente em Crítica Literária - professora adjunta - efetiva da Universidade Estadual Paulista- UNESP/ S. J. Rio Preto. Doutora em Letras Estudos Literários pela mesma instituição. e-mail: cmc.nigro@unesp.br
} 


\section{(PO)ÉTICA QUARE: UM OFÍCIO DE ICONOCLASTIA}

O poeta Waldo Motta é uma reinvenção contínua. Nascido Edivaldo Motta, em 27 de outubro de 1959, em São Mateus, Espírito Santo, já assinou como Valdo Motta, tornando-se, por fim, Waldo Motta, por questões numerológicas. Além de poeta, é ator, numerólogo, místico e agitador cultural brasileiro. Inscrito sob as disposições de uma agenda modernista, foi apontado, por alguns críticos, como uma das mais influentes e ativas (e barulhentas) vozes da poesia brasileira na última década do século XX. É autor prolífico, tendo escrito mais de uma dezena de livros, dentre os quais vale a pena destacar Bundo e outros poemas (Campinas: Editora da Unicamp, 1996), Transpaixão (Vitória: Edições Kabungo, 1999) e Terra sem mal (São Paulo: Patuá, 2015).

Alvo de uma série de apreciações, o controverso Literaturwissenschaftler (cientista das letras) foi considerado um "problema literário" (CALDEIRA, 2008/2009), tendo sua poesia caracterizada como "desbundada" (VIEIRA JR., 2006), e sua poética como "profanada" (SANTOS, 2015) e "maldita" (AZEVEDO FILHO, 2014). Isso não significa, contudo, que a produção desse escritor seja turvada por uma carga negativa. A lucidez do desbunde, da profanação e da maldição propositais cumpre, em Waldo Motta, expedientes outros, expedientes éticos. Tamanha pluralidade de adjetivação se deve, antes, ao fato de sua escrita - marcada com a tinta negra de seu corpo gay - inscrever-se num exercício (est)eticamente poderoso, recorrendo e recolhendo elementos por vezes de origens tão díspares, de campos tão distintos, e operar, à força de um olhar renovado e por efeito de uma ousadia sem precedente, uma transformação, uma (re)criação e uma ruptura de padrões consolidados

Sempre fui considerado um poeta indecente, obsceno. Isto porque eu sempre misturei baixo calão com alto calão. Palavras difíceis, eruditas com palavras sujas, enlameadas, gosmentas. E não só por esta mistura de registros, também pela temática. Eu sempre me assumi como homossexual, não é uma palavra da qual eu goste, mas não tenho outra. E sempre fui muito místico. Logo, nas minhas pesquisas, estudos, aquilo que para muita gente não tem nada a ver eu descobri que tem muito a ver. Sexualidade com religião. O mais chocante de tudo é que nas minhas pesquisas quanto mais eu procuro Deus, o sagrado, eu sempre acabo chegando aos "países baixos", a uma geografia muito interessante do corpo humano. [...] Desde o início da história humana, existem tabus. E o que eu descobri nas minhas pesquisas e que reflete na minha poesia, é que a sexualidade é tanto a perdição quanto a salvação da humanidade. (MOTTA apud VIEIRA JR., 2006, não paginado). 
Voz significativa da poesia brasileira e autor de uma obra emblemática e pungente, não só concebida como objeto de fruição estética e contemplação, mas como uma "crítica que nos obriga a requestionar constantemente o mundo que nos cerca" (PERRONE-MOISÉS, 1990, p. 97), sua produção é cáustica, em certos momentos, por descortinar um sistema social no qual o "eu" e o "Outro" são muitas vezes relegados ao limbo, por se distanciarem dos ditames preconizados pelo hegemônico padrão eurocêntrico, heterossexual, de classe média/alta, e se afirmarem negros, gays, pobres, valorizando a própria identidade. Em especial, quanto à questão da (homos)sexualidade, afirma no prefácio de Bundo e outros poemas (1996), seu livro mais conhecido

\begin{abstract}
$\mathrm{Na}$ metade dos anos 80 comecei a questionar seriamente a homossexualidade e a sexualidade em geral. Já era conhecido por escrever uma poesia desbocada e atrevida, com uma abordagem sincera de minhas experiências. Mas como nem só de escracho se faz arte, passei a estudar tudo o que a cultura pudesse dizer sobre o meu tão singular e problemático comportamento sexual e sobre as desencontradas e conflitivas relações sexuais. (MOTTA, 1996, p. 9).
\end{abstract}

A matéria bruta a ser trabalhada, lapidada, baluarte da escrita de Motta, advém de sua própria e intrínseca condição. Como afirma Amylton de Almeida, "Sem virar o rosto, o poeta desce ao inferno e registra a diferença" (ALMEIDA, 2009, p. 90). Nesse caso, porém, o inferno abrasador é tanto si mesmo quanto seus outros e os Outros - como sustenta Sartre (1977) -, onde se encontram todas as dissimilitudes, as discriminações, onde o desejo quase que permanente é o de (des)habitar o Outro.

$\mathrm{Na}$ edificação de um macrocosmo oracular de linguagem, que encontra a luz no cu de $\mathrm{Exu}^{3}{ }^{3}$ corpo e religião ganham inéditas (e insólitas) significações: o sagrado e o profano se articulam, produzindo um tecido erótico. Opera-se um ofício de iconoclastia, de sacrilégio de ortodoxias sacrossantas, em nome de um relicário da sexualidade. Essa talvez seja justamente a razão pela qual Roberto Schwarz, no texto Por uma experiência brasileira, admita que a produção waldiana, por sua "posição estética, religiosa, sexual e de classe cri[e] ângulos novos" (SCHWARZ, 2000, p. 3). Ângulos esses que despontam em estado de (e)fusão poética, desautomatizando e desarmonizando percepções e olhares, desafiando "o leitor a

\footnotetext{
${ }^{3}$ Faço aqui referência ao poema diminuto, mas lancinante, "NO CU / DE EXU / A LUZ" (MOTTA, 1996, p. 69).
} 


\section{novistet

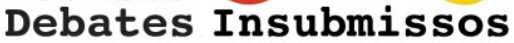

entrar num banquete escatológico, tão difícil quanto necessário" (TREVISAN, 1997, não paginado), compelindo-o a "um escavar de significados, que visa a trazer à luz sentidos soterrados por séculos de sucessivas leituras "espiritualizantes"” (BARCELLOS, 2000, p. 81). Em Waldo Motta, vida e arte se imiscuem numa dinâmica de entrelaçamento e cosedura de filamentos incandescentes de subjetividade e alteridade, num gesto de desfibramento e exaustão da linguagem em toda sua potência, torcendo, aprimorando, alteando e limando a frase na busca do engaste perfeito. Como num pacto primordial, a poesia waldiana anseia "uma linguagem de facas e picaretas, de ácidos e labaredas" que lhe sirva para "execrar, exasperar, excomungar, expulsar, expropriar, expelir, excluir, expurgar, escoriar, expilar, exprimir, expectorar, exulcerar, excrementar (os sacramentos), extorquir, extenuar (o silêncio), expirar.” (PAZ, 1995, p. 159, tradução nossa). ${ }^{4}$ Produto de um processo de reflexão existencial e autoconhecimento, a poesia para Motta é compêndio de seu propósito de vida, legítima profissão de fé. Em outro momento do prefácio de Bundo (1996), chega a explicar que

As virtualidades da palavra e as artimanhas da literatura propiciam requintadas tapeações. Mas, quando aprendi que a poesia caminha em direção oposta à (da) literatura, tomei coragem (eu, que sempre fui poeta) para denunciar o reino das enganações e suas geringonças enganadoras, mostrando como funcionam tais artifícios, exibindo as vísceras das formidáveis patranhas desse monstruário que se fez da logosfera. Minha poesia é uma síntese de meu projeto de vida, uma aventura em busca da Verdade, intuída como a ciência da restauração da condição divina. Se o nome é céu, a palavra é templo e tudo está aqui no corpo, não pode ser outro o sentido do poietes. A transformação se verifica no plano da linguagem, tanto nas palavras quanto no estilo de ser. Não quero apenas escrever mas também ser o que escrevo. Daí o entusiasmo e o tom solene, porque é algo sério; daí o caráter pregacional, mesmo que o meu discurso esteja ainda em construção e suas linhas estruturais às vezes sejam redefinidas em função de necessidades que vão surgindo aos poucos (MOTTA, 1996, p. 10-11, grifos nossos).

Se, conforme afirma, "a palavra é templo e tudo está aqui no corpo", a corporeidade é alçada ao patamar de leitmotiv e se oferece como contraface da normalidade e do enquadramento, que, valorizando uma estética branca, continuamente reforçam estereótipos acerca do homem negro. O poeta-vate excede, portanto, a simples celebração do "corpo elétrico" - como cantado em Folhas de Relva, por Walt Whitman, que também é poeta do

\footnotetext{
${ }^{4}$ un lenguaje de cuchillos y picos, de ácidos y llamas // execrar, exasperar, excomulgar, expulsar, exheredar, expeler, exturbar, excorpiar, expurgar, excoriar, expilar, exprimir, expectorar, exulcerar, excrementar (los sacramentos), extorsionar, extenuar (el silencio), expiar.
} 
corpo (hegemônico) e do desejo - para, imbuído no erotismo místico (ou na mística erótica?), cantar, reclamar e assumir sua materialidade corporal negra, gay, pobre - uma corporeidade imperiosamente quare.

O conceito de quare, como o utilizamos neste trabalho, inscreve-se numa disposição que retira "do gueto os estudos gays e lésbicos, de modo que temas e questões homossexuais [sejam] discutidos em contextos mais amplos" (ALTMAN, 1996, tradução nossa). ${ }^{5}$ Essa corrente está fortemente filiada ao ensaio do professor E. Patrick Johnson denominado “"Quare' studies, or (almost) everything I know about queer studies I learned from my grandmother” [Estudos 'quare' ou (quase) tudo o que sei sobre estudos queer aprendi com minha avó], publicado originalmente em 2001, republicado em 2005, e que, no Brasil, ganha impulso apenas em 2019 com a dissertação de mestrado Diamantes negros sob um arco-íris multicolorido: as identidades negras-gay na poesia de Thomas Grimes, de Fernando Luís de Morais, e com o artigo "De queer a quare: uma aposta interseccional entre gênero, raça, etnia e classe", assinado por Morais et al. Johnson, numa operação de revisionismo e releitura de queer como quare - pronúncia de queer na variante dialetal negra usada pela sua avó distende os marcos das dimensões prototípica, analítica e epistemológica dos estudos queer a fim de abranger questões enfrentadas por lésbicas, gays, bissexuais e transgêneros racializados até então desatendidas por esses estudos. Ao mobilizar as tensões suscitadas entre distintas instâncias identificadoras e idealizar um projeto cujo objetivo cardinal é uma irrestrita inclusividade, o teórico quare por excelência reivindica a legitimação de um "corpo político" que não reduza a identidade a um monólito indivisível, alicerçado a uma compreensão essencialista de raça e gênero, nem elida a materialidade dos corpos, reiteradamente convertidos em um local de trauma, onde coerção e violência racistas e/ou sexistas e/ou homo/transfóbicas são operadas.

Motta, atravessado pela identidade de gênero, raça/etnia e classe que o intersecciona, transplanta as marcas fustigantes e dilacerantes da pele à palavra. Nesse sentido, sua poesia é

\footnotetext{
${ }^{5}$ de-ghettoising gay/lesbian studies, so that homosexual themes and questions began to be discussed in larger contexts.
} 
irrefutavelmente quare, pois refrata mais de um espectro de cores que matizam a identidade do escritor, sufocado pela condição abjeta e subalterna frente aos parâmetros autocráticos.

Comprometido em desabafar liricamente seus sentimentos e trazer à tona, à flor da pele, temas rotulados como periféricos, marginais e aparentemente anti(po)éticos, Waldo Motta resgata o discurso do negro e do homossexual, que amiúde se imbricam. É na insubordinação de sua postura, tal como de seus procedimentos, inevitavelmente amalgamados à obediência à ética, que o poeta descoloniza pensamentos veiculadores de violência contra o "Outro" - e, ao fazê-lo, resgata humanidades. Desse modo, precisa a tônica, o tom e a dicção de sua (po)ética. Quanto à (anti)poeticidade, Oskar Loerke em Da lírica moderna (1912) ensinou, há mais de cem anos, que

[...] queremos incorporar novos vocábulos ao nosso dicionário, em vez de arrancar as folhas velhas; haverá muitas que raramente abrimos, outras foram substituídas e a maior parte permanece insubstituível. Pronto, o dicionário dos poetas, afirmamos: agora não existe nenhum assunto que não seja poético. Todavia, também não existe nenhum que seja poético. E o poeta que se prepare para uma operação do apêndice. Ela revelará como poética ou não-poética a sua arte grande ou pequena. - Queremos propor o catálogo de amostras como dicionário. Bendito seja aquele que destrói as velhas formas e transmite as novas. Aqui, porém, jamais o novo é também o único" (LOERKE, 1912 apud DIAS, p. 56, 1999, grifos nossos).

Em relação à ética e o papel da poesia e, por conseguinte, do poeta, Mario Faustino, em ensaio intitulado "O poeta e seu mundo" (1976), admite que

[...] em questões de poesia, passa-se com facilidade do campo ético para o do estético, e vice-versa. Toda questão se baseia, a meu ver, no fato, por muitos esquecido, que a poesia tem um papel na sociedade, um terreno privado que se não for bem lavrado prejudicará essa mesma sociedade e que aquele papel deve ser exercido pelo poeta com toda a responsabilidade profissional com que uma tarefa de alcance social deve ser empreendida. Enquanto a poesia for olhada apenas como passatempo, como brinquedo inofensivo, como uma coisa de maníacos, de despreocupados, de maus palhaços, ou de ruins carpideiras, não só serão maus uns poetas como estará em perigo a sociedade, cujos poetas não estão cumprindo seu dever. (FAUSTINO, 1976, p. 47).

Os dois fragmentos acima, numa leitura conjugada, indicam que, em seu comprometimento social, o poeta se lança a uma operação com a linguagem, e, muitas vezes, é levado a recorrer a formas desestabilizadoras de percepção, a tratar de temas reputados como "antipoéticos", licenciosos. No entanto, é nessa abertura estrategicamente provocada, nesse inconformismo solapador, nessa "dessacralização" de atributos "pré-fabricados", que a 
contestação ética da lógica supremacista patriarcal-colonizadora é operada. Em Motta, o espírito (santo) subversivo emerge em sua faceta contestadora, transgressora e rebelde e se revela num mosaico de imagens e símbolos parodísticos-sarcásticos, marcando fortemente a vertente de denúncia social de seu projeto que é, ao mesmo tempo, literário e ético.

\section{O PARAÍSO DO CORPO}

O corpo, dentro da concepção (po)ética waldiana, é tomado como lugar sagrado, de culto, configurando-se como templo e também como paraíso. Os corpos trazidos à cena literária por Motta são, contudo, corpos outros, abjetos (BUTLER, 2001), que supostamente "não pesam", porque, dentro de uma lógica cis-heteronormativa, branca e de classe média/alta, não possuem o status de sujeito ou os códigos imprescindíveis daquilo tido como humano. Ao empreender esse projeto, que vimos admitindo ser tanto poético como ético, o escritor, traçando estratagemas e rotas para remir vozes secularmente interditas e inaudíveis, descoloniza perspectivas hegemônicas e opera um exercício de humanização.

"Preceituário para racistas com receita de rebuçado e contra-receita de angu" é um exemplo concreto do que a (po)ética do autor é capaz de formular. O texto evidencia o comportamento renitente do eu lírico - bem como do poeta - frente à castradora realidade que lhe é exterior. Em busca de possibilidades de dizer, por meio de uma linguagem munida de uma manifesta consciência crítica e visceral, construída como resistência às coibições, o poema se oferece como um protesto lancinante:

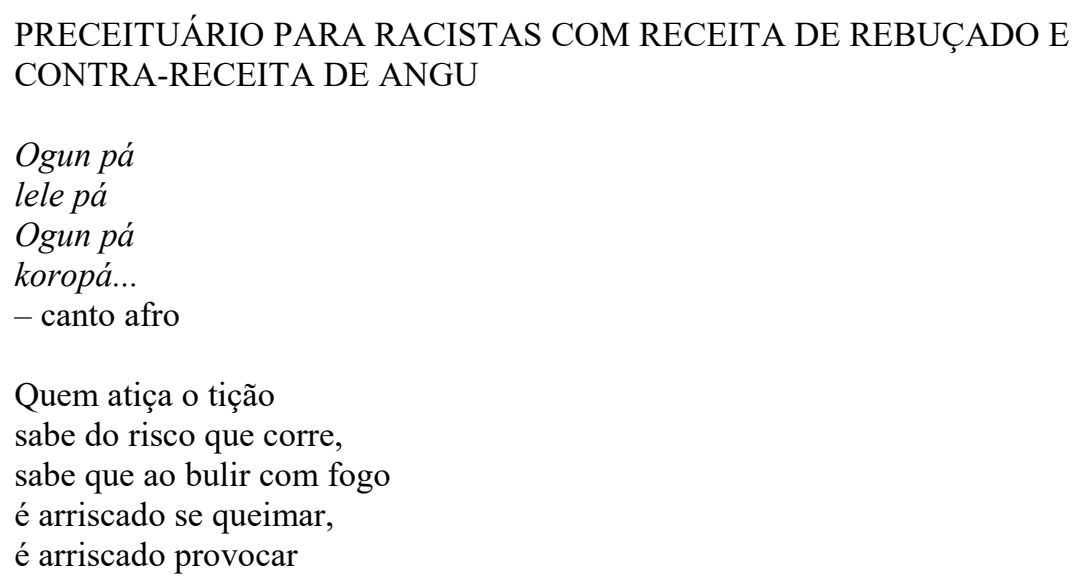




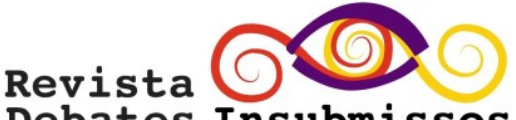 \\ Debates Insubmissos}

a ebulição de quanto
há tanto vem nos enchendo
o caldeirão da paciência.

Portanto, todo cuidado

é pouco quando se atiça

o tição, quando se bole

com o fogo, pelo risco

de transformar rebuçado

em ração para a racinha

ordinária dos racistas.

Quem atiça o tição sabe muito bem do risco de atear fogo em tudo, sabe que, ao provocar a ebulição da massa é arriscado explodir o angu em todo o mundo,

sabe que, súbito, tudo, tudo pode ficar preto $\&$ vermelho, como queiram, num belíssimo incêndio, um incêndio inusitado. Pois quem atiça o tição atira mais lenha aos sonhos que nos abrasam, braseiro oculto sob o borralho dessa vida borralheira. (MOTTA, 1996, p. 98-99).

O texto nasce como preceituário, isto é, um conjunto de regras e normas, voltado a um grupo específico: a saber, os racistas. Nessa prescrição de diretrizes, mescla-se com a receita de uma guloseima e também de outra iguaria. Algo, contudo, causa desconforto, estranha, incomoda. Qual é, afinal, o efeito da aproximação de dois universos - o da raça e o da culinária - aparentemente tão díspares e distantes? Esmiuçando o título a fím de encontrar pistas para uma leitura, percebemos que "rebuçado", além de se tratar de uma "pequena guloseima feita de calda de açúcar endurecida, à qual se acrescentam corantes e/ou ingredientes ou essências de vários sabores, e que se vende embrulhada em papel" (HOUAISS, 2009), refere-se igualmente a uma "observação desagradável; reprimenda" (HOUAISS, 2009). “Angu”, por sua vez, além de significar "massa espessa que se faz misturando, ao fogo, farinha de milho (fubá), de mandioca ou de arroz, com água e, às vezes, 
sal" (HOUAISS, 2009), diz respeito à "falta de ordem; [...] confusão, complicação" (HOUAISS, 2009). Eis que o título passa então a sugerir mais, a revelar mais. Motta preanuncia, já na denominação do poema, que nos está colocando diante de uma produção agenciada por meio de ambiguidades, de anfibologias ostensivamente refletidas.

"Preceituário para racistas" se inicia com uma epígrafe que recorre ao canto afro “Ogun pá / lele pá / Ogun pá / koropá...”, equivalente em tradução a “Ogum mata com violência / Ogum mata e destrói completamente” (AUGRAS, 2008, p. 102). Esses versos já nos dão a perceber a índole beligerante, voraz e sanguinária de Ogum. O protagonista a que se faz alusão é uma divindade iorubá, arquétipo do guerreiro, e uma das figuras mais poderosas do panteão dos orixás. Associado diretamente à honra, um de seus maiores entusiasmos é lutar pela justiça. Ao se lançar aos ataques, quando irado, é impiedoso, cruel, implacável, devastadoramente destruidor e colericamente vingativo. Ogum, filho de Iemanjá com Oranian, é senhor dos exércitos e das armas, o orixá das contendas, o deus da guerra, e carrega no próprio nome essa marca ("Ogum”, em iorubá, significa "luta”, "guerra”). Além disso, é o deus do ferro, do aço, da metalurgia, a divindade que brande a espada e forja o metal, de modo a transformá-lo em instrumento de luta. Nessa lógica, seu poder vai propagando-se para além dos combates, sendo o patrono de todos aqueles que manejam ferramentas: ferreiros, barbeiros, militares, soldados, para ficarmos com alguns exemplos. Em texto intitulado "Ogum" (2001), Marlúcia Mendes da Rocha, professora da Universidade Estadual de Santa Cruz (UESC), afirma que

$\mathrm{Na}$ África, Ogum é considerado o mais famoso defensor das causas humanas [...] é um orixá de muita popularidade. É a representação do escravo reprimido, apartado e isolado de sua terra, de seu papel e valor social. [...] Um filho de Ogum segue o seu arquétipo. Pessoa objetiva, de uma franqueza rude, da fala direta, sem rodeios (ROCHA, 2001, p. 15).

Em “Os orixás e seus poderes”, assinado por Pai Valdevino de Alafin, consta que

Ogum representa a eterna luta a favor da paz universal, a luta do espírito contra a matéria, a luta do ser humano para a sua purificação assim como acontece com o aço e o ferro quando são aquecidos e transformam-se em ferramentas cada vez melhores, assim é a luta de OGUM a favor do ser humano para que nos transformemos em pessoas melhores, através das lutas, das guerras, dos derramamentos de sangue, através das disputas, com o poder do ferro e do aço que é dominado por OGUM, com as sete espadas de OGUM, as sete forças de OGUM, o senhor do número 7. Pelas forças de OGUM todos renascemos melhores em espírito, e de renascimento 


\section{Revista \\ Debates Insubmissos}

em renascimento, de transformação em transformação, chegamos mais perto do ALFA, mais perto do mais que perfeito, mais perto da luz mais branca que o Universo pode conceber, pois foi concebido por ELE o nosso PAI CRIADOR DO INFINITO. (ALAFIN, [201?], não paginado).

É justamente na defesa das causas humanas, "[n]a eterna luta a favor da paz universal" e na "franqueza rude" que Waldo Motta se aproxima de Ogum, desfere suas censuras e desaprovações, forjando ferramentas poéticas, martelando ritmos, moldando a sintaxe do texto, confeccionando, por fim, um poema-arsenal. O orixá é revisitado tanto no tema quanto na forma do poema.

$\mathrm{Na}$ feitura dos versos, Motta efetua uma apropriação interessante - mas não exatamente explícita - que só se dá a conhecer a partir das informações que circundam a figura do deus Ogum. De acordo com a mitologia africana, o orixá é associado ao número sete, por motivo de uma luta travada com Iansã, na qual esta foi mutilada em nove pedaços, e aquele, em sete. Nesse sentido, em diálogo com a narrativa mitológica, o poeta - que também é numerólogo - resgata, na arquitetura dos versos, o número simbolizador da perfeição. Formalmente, as estrofes se assentam, portanto, sobre os heptassílabos (redondilha maior), estabelecendo tanto um pacto com o mito de Ogum como imprimindo um ritmo todo particular ao poema, que nos remete às batidas de tambor de um ritual africano sagrado. A redondilha maior - vale lembrar - é o modelo de versificação mais popular em língua portuguesa, pois "cabe na boca e gruda na memória" (SQUARISI, 2011, não paginado). Dessa forma, a melodia do preceituário, que fica "martelando" e reverberando na memória, pode facilmente servir de lição a ser retida pelos racistas - mas não só. Para efeito de demonstração, tomemos a escansão dos versos que compõem a primeira estrofe:

\footnotetext{
Quem/a/ti/ça/o/ti/ção $\mathrm{sa} / \mathrm{be} / \mathrm{do} / \mathrm{ris} / \mathrm{co} / \mathrm{que} / \mathrm{co} / \mathrm{rre}$, sa/be/queao/bu/lir/com/fo/go éa/rris/ca/do/se/quei/mar, éa/rris/ca/do/pro/vo/car $\mathrm{a} / \mathrm{e} / \mathrm{bu} / \mathrm{li} / \mathrm{ção} / \mathrm{de} / \mathbf{q u a n} /$ to há/tan/to/vem/nos/en/chen/do o/cal/dei/rão/da/pa/ciên/cia.
}

A primeira estrofe se abre com dois versos que, de antemão, delineiam o tom áspero de reprimenda que reveste o eixo nuclear entorno do qual o poema gravita: "Quem atiça o 
tição / sabe do risco que corre". Em outros termos, aquele que atiça é caracterizado como consciente dos impactos e implicações de seus atos, de seus feitos. Não se encontra, em vista disso, em posição de neutralidade e não pode alegar qualquer tipo de imparcialidade ou isenção. Os versos, assim como o título, são armados de ambiguidade: "atiçar" é avivar o fogo, mas, ao mesmo tempo, provocar a ira, exasperar; "tição", por sua vez, faz referência tanto a um pedaço de lenha acesso, mas, de forma excessivamente pejorativa e estigmatizante, caracteriza um indivíduo negro em razão das marcas de sua materialidade corporal. Atiçar o tição, numa leitura primeira e/ou mais despretensiosa, é tão somente espertar o carvão aceso; num nível mais profundo - e é esse que nos interessa -, é incitar a cólera do sujeito negro.

Vítimas de uma política imperialista devastadora e inclemente, que exerce a violência como forma de invalidar outros modos de ser, os sujeitos negros carregam uma série de máculas desde o período escravocrata. Assim, dentro de um quadro pautado em um protótipo hegemônico de humanidade, são vistos como libidinosos, agressivos, emotivos, bárbaros, hipereróticos; são, como exposto por Deivison Faustino, "corpos selvagens e incivilizados, e não sujeitos de si. São apenas escravos do desejo dos verdadeiros sujeitos - os brancos. Os negros e as negras não são nada!" (FAUSTINO, 2019, p. 15). Ao eleger o signo "tição", trabalhado em sua polissemia, as representações negativas que recaem sobre a corporeidade negra são, portanto, trazidas à tona. O corpo, quando comparado ao tição, é subjugado à condição de objeto, de abjeção, de inaceitabilidade por códigos de inteligibilidade (BUTLER, 2002). Contudo, a estratégia discursiva de Motta - ela mesma violenta, vista que embasada nos preceitos de Ogum -, opera na contracorrente de clichês raciais, rechaçando esses rótulos consolidados. A leitura segunda, mais minuciosa e ponderada, possibilita entrever uma crítica férrea - própria do transbordamento do caldeirão da paciência - que, num nível primeiro, encontrava-se rarefeita, ainda em estado de iminência. Com efeito, reside no jogo articulado pelas ambiguidades o estratagema engendrado na construção do poema.

Nos versos posteriores, o risco é trazido à baila: "se queimar" e "provocar a ebulição", ações desencadeadas a partir do fato de bulir com o fogo. A consequência iminente dessa fervura é o transbordamento do "caldeirão da paciência" que "há tanto vem nos enchendo" ou que há tanto vem enchendo-se até atingir o ponto extremo de saturação - e a efusão da 
mistura, que inevitavelmente causará as queimaduras, deflagrará um desfecho abrasador. É interessante notar como a ideia do campo imagético atrelado ao elemento fogo ganha força, pujança, e o quanto é ardente. Significativo, aliás, porque Ogum, referenciado na epígrafe, além de manipulador do ferro, o é também do fogo. Ogum é o fogo da salvação, da glória e da inovação.

A transformação, derivada da ebulição na primeira estrofe, transvaza e esparge pelos versos da segunda: "transformar rebuçado / em ração para a racinha / ordinária dos racistas". Novamente, Ogum se presentifica por meio da ideia da transmutação. Há um devir franqueado de possibilidades que se instauram pelo jogo sonoro: o emprego do fonema fricativo velar /x/, representado graficamente pela letra "r" em "rebuçado" "ração", "racinha" e "racista", causa um desconforto, um ruído, assim como a mensagem cinzelada nos versos. Ademais, produz um efeito de aspereza, de rispidez, característico do próprio tom do poema trata-se, afinal, de um preceituário marcado pela "franqueza rude" própria dos filhos de Ogum. Motta opera ainda uma manipulação das palavras "rebuçado" (= alimento ou reprimenda), "ração" (= alimento ou aumentativo de "raça") e "racinha" (= diminutivo de raça). Portanto, ao preconizar "transformar rebuçado / em ração para a racinha / ordinária dos racistas", a possibilidade interpretativa é novamente amplificada: tanto se oferece um alimento - neste caso indigesto, porquanto incrustado de reprimendas - ao grupo desprezível (marca provocada pelo uso do diminutivo e intensificada pelo signo "ordinária") dos racistas, quanto se oferece a própria reprovação que parte da raça negra (cujo status agora ganha expressividade pelo uso do aumentativo) e é direcionada à raça ordinária dos que se configuram como racistas.

A questão do risco e da provocação é retomada na terceira estrofe. A estratégia de deslocamento e renovação de sentidos é outra vez armada e a(mar)rada pelo jogo polissêmico - e não gratuito -, assentado agora entre "massa" e "angu", que inflamam distintas possibilidades interpretativas. O primeiro termo faz referência à substância pastosa com a qual se prepara um determinado alimento, mas também ao grande número de pessoas vistas do ponto de vista social, cultural e econômico - aqui, no caso, os negros. Os segundo, por sua vez, remete tanto ao significado primeiro, dentro do campo semântico da culinária, quanto à 
ideia de confusão e desordem. Nessa lógica, "provocar / a ebulição da massa" e "explodir / o angu em todo mundo" pode ser lido, uma vez mais, como a exasperação do povo negro e a consequente deflagração de uma confusão - o que retoma as disposições da estrofe anterior, concatenando-as e avivando-as. Sob o signo da crítica, da inovação e da resistência, o texto subverte tanto pelo uso que faz da linguagem quanto pela atitude das regras nele delineadas.

As ressonâncias e efeitos do atiçamento do tição, da agitação incessante com o fogo, da ebulição da massa e da explosão do angu em todo mundo eclodem e entram em combustão na estrofe final. É ali, naqueles versos, que "tudo pode ficar preto / \& vermelho". Não é possível deixar de perceber a matização imposta à vista, imprimindo sua marca. "Ficar preto" confere a sensação de seriedade e hostilidade, mas também de respeito, autoridade e morte. $\mathrm{O}$ vermelho, em contrapartida, traduz a cor do fogo e do sangue, e, por isso, associa-se às ideias de energia, de guerra, de perigo, de força, de poder. Preto e vermelho se consubstancializam, então, não só no substrato sintático - a partir do uso do símbolo ampersand -, mas também no substrato semântico. O incêndio - já adiantado pela coloração do verso anterior - parece lançar labaredas e se propagar no quarto verso da última estrofe ("num belíssimo incêndio"), onde, caracterizado ironicamente pelo adjetivo "belíssimo", empregado no grau superlativo absoluto sintético, de fato, irrompe. O que sobra dessa combustão irrefreada e calcinante, o boralho da estrofe, é um desfecho-reverbério: "Pois quem atiça o tição / atira mais lenha aos sonhos / que nos abrasam, braseiro / oculto sob o borralho / dessa vida borralheira." $\mathrm{Na}$ linguagem direta e abrasadora dos filhos de Ogum, a mensagem que crepita desses versos é: em um mundo onde rígidas hierarquias ainda sustêm o corpo hegemônico branco como o ideal de humanidade, o corpo negro, objetificado, reclamando o que lhe foi espoliado, ainda resiste.

Entoado pelo mesmo discurso de resistência e reconhecendo a identidade (e, consequentemente, o corpo) como questão pessoal e política, Waldo Motta resgata e retraça a "marginalidade", o aviltamento de alteridade manifesto por meio das múltiplas opressões. "Deus furioso" é resultado dessa consciência (po)ética 


\section{goritat 6 \\ Debates Insubmissos}

DEUS FURIOSO

Estendi mãos generosas

a quantos o permitiram

e disse: sou Deus.

Porém, quem acreditou?

Fui humilhado, escarnecido: Deus viado? Fui negado e combatido.

Em meu amor entrevado cerrei lábios e ouvidos. Até o amor reprimido virar ódio desatado.

Rasguem céus e infernos, ó gemidos e brados de amor ressentido. Raios partam quantos meu amor tenham negado. Prorrompam tormentas em corações petrificados, Quero ser amado quero ser amado quero ser amado

(MOTTA, 1996, p. 48).

Nessa produção, o tema aparentemente antipoético da homossexualidade, visto que tabu, ganha poeticidade e atravessa o âmbito do sagrado. Motta, num exercício sóbrio de reflexão, poderia repercutir toda sua materialidade corporal negra-gay-pobre ao longo desses versos - em razão de sua poesia ser uma síntese de seu projeto de vida, como ele mesmo afirma. Diferentemente do poema anterior, respaldado na questão da raça, neste, aborda a questão da sexualidade. Esse tratamento, embora fragmentário - a considerar pelo impacto que as distintas vias opressivas do gênero, da raça/etnia e da classe provocam na vida do poeta -, é altamente relevante. Dito de outra forma, o discurso de Motta representa a liberação de um grito aguerrido que viola o abafamento da voz - um grito que perfura os ares, os muros, os tímpanos, estilhaçando formas lineares e antediluvianas de pensamento. Em Motta, as leituras se pluralizam, (re)elaborando tráfegos identitários.

A primeira estrofe, marcada pelo tom memorialístico, evoca as lembranças calamitosas de um tempo pretérito: o fato de estender as mãos generosas, de ser renegado como Deus, de ser "humilhado" e "combatido", flagelos desencadeados a partir da revelação 
de ser "viado". O sujeito lírico já se "corporifica" desde o primeiro verso, não só pela marcação da desinência número-pessoal em "estendi”, mas pelo uso metonímico da expressão "mãos generosas", que toma a figura das mãos para desdobrar a qualidade ao próprio "eu”, a se revelar, no sexto verso, como "Deus viado". A generosidade, qualidade inerente ao sujeito que então se apresenta, só pode ser aceita ao passar pelo crivo e pela admissão por parte do "Outro". Assim, no recôndito do verso, está instaurada uma relação identitária - que se verá conflitante - entre o "eu" (Deus) e o "Outro" (o humano), da subjetividade frente à alteridade.

Ao priorizar a grafia com letra maiúscula, particulariza-se o "Deus" aludido: o "Ser primordial responsável pela origem do universo, das leis que o regulam e dos seres que o habitam, fonte e garantia do Bem e de todas as excelências morais" (HOUAISS, 2009). Logo, essa dinâmica procedimental externa a ironia do poeta, pois, como sugerido no título do poema, esse Deus é contaminado pela fúria, pela cólera, atributos inerentemente humanos, mundanos. O leitor é orientado, uma vez mais, a presenciar um exercício de profanação. Algo particularmente interessante é a presença do divino e do humano na organização formal do próprio texto, que, na primeira estrofe, focaliza a corporeidade do Deus "viado" e as ações que sobre ele recaem e, na segunda, passa a evidenciar a irascibilidade desse ser supremo, agora suplantado à condição humana.

Como reação às negações ("Fui negado e combatido"), o eu enunciador, em um movimento de reclusão, enclausura-se em sua órbita de sofrimento, cerrando lábios e ouvidos. Outra consequência do malogro desse amor onipotente é o ultraje, que o solapa ao ponto do descrédito. O "amor reprimido", posto que "viado", é sintomático em sujeitos homossexuais, cuja liberdade é cerceada, circunscrita. Dentro de uma lógica heteronormativa, trata-se de um amor desautorizado, ilegítimo, inautêntico porque se configura entre "subalternos" (SPIVAK, 2010).

Ao jogar com a concepção de um "Deus viado", Waldo Motta dinamita as probabilidades e perspectivas hegemonicamente inabaláveis. Diante do inusitado, do insólito, do excêntrico, o leitor é conduzido a desacomodar os códigos e a questionar a desumanização ocasionada pela homofobia e pelos discursos conservadores, inflexíveis em suas 


\section{nevistat 0 \\ Debates Insubmissos}

determinações de aviltar, apagar e silenciar o que é diferente, o que foge à normatização. Quanto à questão da orientação sexual relatada no poema, Camargo e Santos sustentam que

A orientação sexual daquele que se intitula Deus, coloca-o em face do descrédito e da irrelevância. De "Deus" a "Deus viado", o eu se nota rotulado e estereotipado. O ato de criação do poeta Waldo Motta não abandona as paradoxais relações que travamos com nossa sexualidade. $\mathrm{E}$ isto nos exige, necessariamente, voltar-nos para uma temática que ainda, na atualidade, é um tabu (CAMARGO; SANTOS, 2018, p. 35).

Os autores especificados salientam a interdição da homossexualidade (negra e pobre, se tomarmos como referencial a figura de Motta), questão que requer discussões mais substanciais e construtivas. O corpo quare insurge como um inventário de possibilidades, confrontando silêncios, deslocando e convulsionando discursos, demandando não só uma gramática mais prismática, mas também zonas habitáveis do ser. Motta, em seu afã incansável, vai entrelaçando fios, tecendo textos, oportunizando a composição dessa gramática antirracista, anti-homofóbica, anticlassista, de complexas e revalorizadas tessituras corporais.

Elaborada integralmente por formas verbais conjugadas no pretérito perfeito (“estendi”, “disse", “acreditou”, "fui”, “cerrei”), a primeira estrofe determina a urgência de um olhar voltado ao passado injurioso e ultrajante. Sinaliza, assim, um momento de dor, de afrontas e sujeições. A cólera daí irrompida é desferida como um golpe rompante a ser consumado na segunda estrofe. O ofício e a índole divinos, que a princípio suscitam estranhamento, então se justificam. À semelhança de um exercício de iconoclastia, a imagem de Deus como proveniência suprema de amor e compaixão é esfacelada e substituída por uma de um "Deus furioso" pela injustiça recaída sobre si. A concepção cristã de "Deus é amor" vai ruindo-se e desmantelando-se ao longo de seis versos, como efeito de uma gradação das ações, bem realçadas pelas rimas em "ado" e "ido", na primeira estância do poema: "humilhado", "escarnecido", "negado", “combatido", “entrevado", "reprimido".

Na segunda estrofe, o ódio se desata, fazendo eclodir um turbilhão de sentimentos. A voz enunciada é infundida de exigências e demandas, ordenando os "gemidos e brados / de amor ressentido" a rasgarem céus e infernos, convocando os raios a partirem todos aqueles cujos corações insensíveis e impiedosos preteriram o amor que lhes fora devotado. A inversão 
sintática em "Rasguem céus e infernos, / ó gemidos e brados / de amor ressentido", quando o mais natural seria iniciar com o vocativo, destaca a veemência e a expressividade do imperativo "rasguem", e, por conseguinte, da fúria. Com efeito, a estrofe cinde formalmente o poema no intervalo da passagem do sublime ao terreno, do sagrado ao profano. $\mathrm{O}$ eu poemático reivindica, então, o seu desejo maior: ser amado. O verso "Quero ser amado", reiterado três vezes consecutivas, arrematando o poema, que termina sem pontuação, reproduz não só um sentido de persistência, mas também de ininterrupção. São versos que, por estarem no presente do indicativo, intensificam-se em determinação, ressoando como clamor e protesto. Dito de outra forma, é a voz do "eu” forçando um grito rasgado, um apelo inadiável por reconhecimento e aceitação - apelo esse que fende céus e infernos.

Se em "Deus furioso" e em "Preceituário para racistas" Motta trabalhava, isoladamente, na construção de um discurso anti-homofóbico e antirracista, em "No cu", há, embora de forma implícita, uma intersecção entre esses dois discursos:

\section{NO CU \\ DE EXU \\ A LUZ}

(MOTTA, 1996, p. 69).

Grafado/gritado em letras garrafais, e, portanto, altissonante, o diminuto porém categórico poema se anuncia. Composto de três versos rimados, com duas sílabas poéticas cada, o corpo textual está erigido, sintaticamente, a partir de apenas duas estruturas: um adjunto adverbial de lugar e um sujeito. Em sua brevidade e rapidez de compasso, responde a três perguntas essenciais: “onde?”, “de quem?” e “o quê?”, determinando com exatidão o local de resplandecência da luz. O encontro com a luz é atravessado por um senso de urgência, que se faz notar pela ausência de qualquer tipo de pontuação e pela omissão do verbo que estabeleceria o vínculo entre os dois primeiros versos e o último.

No percurso pela descoberta da luminescência, Waldo Motta efetua manobras transgressivas, cujo intento é tensionar e convulsionar a "castidade" de uma lógica alicerçada sobre preceitos cristãos, brancos e heterossexuais. Essas violações, juntamente com os excessos, constituem elementos basais à revitalização do erotismo. A propósito, o pensador 
francês Georges Bataille corrobora o fato de que "O mundo sagrado abre-se a transgressões ilimitadas." (BATAILLE, 1987, p. 63). Um desses casos de contravenção parece ser o estabelecimento de uma inusitada identificação entre o ânus e Deus, representado por Exu, seu correlato nas religiões de matriz africana. Conceituado como uma das principais divindades do iorubá e do jejê, Exu, também conhecido como Esu, Eshu, Bará, Ibarabo, Akésan, Yangí, Legbá, Ònan, é, no panteão africano, o orixá da comunicação, da paciência, da ordem, da disciplina e da sexualidade, tendo um forte domínio sob o sexo, a magia, a união, o poder e o fogo da transformação. De acordo com a matéria “O que é um Exu” (2018), assinada por Bruno Lazaretti e veiculada pela Revista Super Interessante, "No candomblé, Exu é um dos maiores orixás [...]. É uma espécie de mensageiro, que faz a ponte entre o humano e o divino e muitas vezes é descrito como sendo travesso, fiel e justo." (LAZARETTI, 2018, não paginado). É, aliás, reputado como a divindade mais humana dentre os outros orixás. Um ponto digno de atenção é o fato de que, diferentemente do que ocorre em religiões monoteístas, as divindades africanas não são caracterizadas dentro de um plano maniqueísta, isto é, não são catalogadas como boas ou más. Talvez, seja essa uma das razões pelas quais existam diversas confusões e conceitos controversos quanto às origens e atuação de Exu. Um dos equívocos mais corriqueiros é associar a figura desse orixá à do diabo cristão. Nesse quadro imaginário perverso e fomentador de estereótipos, ele é tratado como um deus replicador da maldade e da atrocidade, semeador da discórdia humana.

Exu, no poema, substancializa a imagem do imaculado, do inviolável, em uma cultura de origem negra, "assombrada pelo discurso homogeneizante e [...] alienante do cristianismo" (SANTOS; PEREIRA, 2012, p. 94); o cu, por sua vez, uma das chancelas do erotismo, ascende a um status divinizado porque, contendo a luz (lida também como metáfora do conhecimento, da sabedoria), simboliza o acesso, o ponto de correspondência do mundano com Exu. Como numa via crucis do corpo, parte-se do escatológico, do baixo-corporal, rumo ao divino, ao sagrado - é, afinal, no corpo (negro) de Exu que a luz se torna presente. A sonoridade corrobora essa trajetória: a vogal alta posterior arredondada $[\mathrm{u}] \mathrm{em}$ "cu" e "Exu" atualiza a sensação de escuridão, de obscuridade, de sujidade, de negritude, latente nesses signos; em "luz", contudo, a mesma vogal [u], sob o efeito da fricativa alveolar desvozeada 
[s], ilumina-se em toda sua resplandecência e claridade. No último verso, como num arremate exuberante, a luz se faz: Fiat lux!

Recorrer à figura de Exu não é mero acaso, pois, espelhando o poeta em sua compleição - Exu pode ser lido igualmente como $\mathrm{E}(\mathrm{x}) \mathrm{u}$-, a divindade é interseccionada pelos vetores da raça e da sexualidade. Como efeito irônico de uma construção que se dá às avessas, Waldo Motta, como num sopro divino, recria um outro "(D)eu(s) viado". Instalar a luz "No cu / de Exu" sugere não só a profanação da divindade, mas também do local intocável e sustenedor da masculinidade heterossexual. Violar o "santuário sedal" é fazer ruir, imperiosamente, a heterossexualidade em toda sua hombridade. Ao colocar em cena o corpo quare, par excellence, Motta está, a um só tempo, ressignificando as formas de ser um homem negro numa sociedade heteropatriarcal branca e tecendo uma crítica virulenta ao sistema secular que, ainda hoje, perpetua a heterossexualidade e a branquitude como padrões de humanidade:

A norma homem-branco-hétero exerce sobre as demais subjetividades um efeito colonizador e extrativista. Colonizador no sentido de impor-se violentamente sobre o outro por considera-lo menor. Extrativista no sentido de sugar a energia vital de quem está fora da norma por meio de violentos processos de submissão. [...] Narciso acha feio o que não é espelho. (VEIGA, 2019, p. 77).

É na amplificação de possibilidades semânticas e no manejo poético da linguagem de modo a incorporar a esfera do chão à do sublime que uma erótica fundada e sustentada no espiritual se torna notória. Assim, a sacralização do corpo e da experiência carnal da homossexualidade negra ganham cena dentro da poética waldiana.

\section{CONSIDERAÇÕES}

Em suas ilimitadas inovações e transgressões, a (po)ética de Waldo Motta é desafiadoramente aguda. Empreendendo, sobre o terreno de uma singularidade expressiva, a cartografia e a reterritorialização de corpos situados fora da norma, leva-nos a reexaminar as disposições de poder reguladoras de nossa sociedade, fundada sobre os baluartes unificadores do heteronormativismo branco. Dito de outra forma, a poesia waldiana, eticamente articulada (ou tratar-se-ia, antes, de uma ética poeticamente articulada?), incita-nos a repensar os corpos 
abjetos, os corpos quare, interditos, privados de transitar por espaços predefinidos. Eis aí que o poeta, desvencilhando-se das malhas do discurso unívoco, dá-nos a ver o desejo de legitimação e de tirania, o desejo de habitar o Outro ou desabitá-lo.

Em seu ofício árduo e incessantemente comprometido com o social, Motta representa não só a voz de júbilo que canta a sacralidade do corpo negro e gay, mas também a voz incansável que clama e, entoada num timbre abrasador, ateia fogo às predisposições hegemônicas, devastadoras e dizimadoras de humanidades. Ao incandescer os versos e iluminar a procura do profano no divino e do divino no profano, o poeta, num processo estratégico de reversão de discursos normalizadores e reacionários, problematiza, desconstrói, mina, escava, perturba, subverte e esfacela estruturas domesticadas e domesticadoras do conhecimento calcado numa visão supremacista. Nesse sentido, é impertinente, irreverente, perverso, subversivo, profano, extraindo o gozo do corpo, que é, a um só tempo, templo destinado ao culto e paraíso. E falou Waldo Motta, dizendo: "atiçai-me o vosso fogo / dai-me as graças do gozo / das delícias que guardais / no paraíso do corpo.” (MOTTA, 1996, p. 45).

\section{REFERÊNCIAS}

ALAFIN, Valdevino. Ogum. [s.d.] Disponível em http://www.umbandadanatureza.com.br/OX006.HTML. Acesso em: 01 nov. 2019.

ALMEIDA, Amylton. Amylton Almeida. In: MOTTA, Waldo. Transpaixão. 2. ed. Vitória, ES: EDUFES, 2009. p. 90.

ALTMAN, Dennis. On Global Queering. Australian Humanities Review, v. 2, jul. 1996. Disponível em: < http://australianhumanitiesreview.org/1996/07/01/on-global-queering/ >. Acesso em 29 ago. 2018.

AUGRAS, Monique. O duplo e a metamorfose: a identidade mítica em comunidades nagô. 2. ed. Petrópolis, RJ: Vozes, 2008. 
AZEVEDO FILHO, Deneval Siqueira de. A poética maldita de Waldo Motta: melancolia e desencanto na marginalidade periférica. Revista Estação Literária, Londrina, v. 12, p. 272283, jan. 2014.

BARCELLOS, José Carlos. Poéticas do masculino: Olga Savary, Valdo Motta e Paulo Sodré. In: PEDROSA, Celia (Org.). Mais poesia hoje. Rio de Janeiro: 7 Letras, 2000. p. 77-86.

BATAILLE, Georges. O erotismo. Tradução de Antonio Carlos Viana. Porto Alegre: L\&PM, 1987.

BUTLER, Judith. Corpos que pesam: sobre limites discursivos do "sexo". In: LOURO, Guacira Lopes. O Corpo Educado: pedagogias da sexualidade. Belo Horizonte: Autêntica, 2001.

BUTLER, Judith. Entrevista. In: PRINS, Baukje; MEIJER, Irene Costera. Como os corpos se tornam matéria: entrevista com Judith Butler. Revista de Estudos Feministas, v. 10, n.1. Florianópolis, 2002. Disponível em: http://www.scielo.br/scielo.php?pid=S0104026X2002000100009\&script=sci_arttext. Acesso em: 01 nov. 2019.

CALDEIRA, Rodrigo Leite. Waldo Motta: poesia, crítica e problema. Revista Contexto, Vitória, n. 15 e 16, p. 334-345, 2008/2009.

CAMARGO, Fábio Figueiredo.; SANTOS, Ricardo Alves dos. Bicha preta reza o corpo.

Revista Língua \& Literatura, v. 35, n. 20, p. 31-42, Jan./Jun. 2018.

FAUSTINO, Deivison Mendes. Prefácio. In: RESTIER, Henrique.; SOUZA, Rolf Malungo. (org.). Diálogos contemporâneos sobre homens negros e masculinidades. São Paulo: Ciclo Contínuo Editorial, 2019. p. 13-20.

FAUSTINO, Mário. Poesia-experiência. São Paulo: Perspectiva, 1976.

HOUAISS. Dicionário eletrônico Houaiss da língua portuguesa. Rio de Janeiro: Objetiva, 2009. 
LAZARETTI, Bruno. O que é um Exu? Entenda a divindade, parte do candomblé e da umbanda. Super Interessante, 04 jul. 2018. Disponível em:

https://super.abril.com.br/mundo-estranho/o-que-e-um-exu/. Acesso em: 01 nov. 2019.

LOERKE, Oskar. Da lírica moderna. In: DIAS, Maria Heloísa Martins. A estética expressionista. Cotia: Íbis, 1999. p. 55-60.

MORAIS, Fernando Luís de. Diamantes negros sob um arco-íris multicolorido: as identidades negras-gay na poesia de Thomas Grimes. Orientadora: Cláudia Maria Ceneviva Nigro. 2019. 150 f. Dissertação (Mestrado Teoria da Literatura) - Universidade Estadual Paulista (Unesp), Instituto de Biociências Letras e Ciências Exatas, São José do Rio Preto, 2019.

MORAIS, Fernando Luís de. et al. De queer a quare: uma aposta interseccional entre gênero, raça, etnia e classe. Itinerários, Araraquara, n. 48, p. 61-76, jan./jun. 2019.

MOTTA, Waldo. Bundo e outros poemas. Campinas: Editora UNICAMP, 1996.

PAZ, Octavio. Libertad bajo palavra: obra poética (1935-1957). México: Fondo de Cultura Económica, 1995.

PERRONE-MOISÉS, Leyla. Literatura comparada, intertexto e antropofagia. In: PERRONEMOISÉS, Leyla. Flores da escrivaninha: ensaios. São Paulo: Companhia das Letras, 1990. p. 91-99.

ROCHA, Marlúcia Mendes da. Ogum. In: Revista Kawé. Ilhéus, n. 2, p. 14-16, 2001.

SANTOS, Ricardo Alves dos. A poética profanada de Waldo Motta. Revista Estação Literária, Londrina, v. 13, p. 40-61, jan. 2015.

SANTOS, Ricardo Alves dos.; PEREIRA, Kênia Maria de Almeida. Os mitos africanos e a lírica de protesto na poesia contemporânea de Waldo Motta. Texto Poético, v. 12, p. 94-106. 2012.

SARTRE, Jean-Paul. Entre quatro paredes. São Paulo: Abril, 1977. 
SCHWARZ, Roberto. Por uma experiência brasileira. Entrevista de Roberto Schwarz a Eduardo Nassi. Porto Alegre: Zero Hora, 01.07.2000, Cultura, p. 3.

SPIVAK, Gayatri Chakravorty. Pode o subalterno falar? Trad. Sandra Regina Goulart Almeida; Marcos Pereira Feitosa; André Pereira. Belo Horizonte: Editora da UFMG, 2010. SQUARISI, Dad. A redondilha cola na memória. 2011. Disponível em:

http://blogs.correiobraziliense.com.br/dad/a redondilha cola na memoria/. Acesso em: 01 nov. 2019.

TREVISAN, João Silvério. Enjoo Poético. Trechos da apresentação de entrevista de Valdo Motta a João Silvério Trevisan. In: Suigeneris, n. 23. São Paulo, 1997. Entrevista.

VEIGA, Lucas. Além de preto é gay: as diásporas da bixa preta. In: RESTIER, Henrique.; SOUZA, Rolf Malungo. (org.). Diálogos contemporâneos sobre homens negros e masculinidades. São Paulo: Ciclo Contínuo Editorial, 2019. p. 77-93.

VIEIRA JR., Erly. A desbundada poesia erótico-mística de Waldo Motta. [s. l.] 2006.

Disponível em: http://www.overmundo.com.br/overblog/a-desbundada-poesia-eroticomistica-de-waldo-motta. Acesso em: 01 nov. 2019. 